
університету. - Серія "Регіональна економіка". - Випуск 16 (63). - Редкол.: відп. ред. д.е.н., професор Л.Л. Ковальська - Луцьк : ІВВ Луиького НТУ, 2019. - 173 с.

УДК 338.48

Погуда Н.В., к.е.н., доцент

Харківський національний економічний університет імені С. Кузнеця

\title{
ТУРИЗМ ЯК ІНДИКАТОР РОЗВИТКУ ЕКОНОМІКИ
}

У статті розглянуто сучасні індекси оцінки розвитку економіки країни. Проаналізовано динаміку валового внутрішнього продукту та динаміку зростання доходів від надання туристичних послуг. Встановлено, що між показником ВВП та розвитком туризму існує тісний зв'язок. Визначено необхідність розвитку туризму як індикатора розвитку економіки.

Ключові слова: туризм, індикатор, валовий внутрішній продукт, індекс розвитку.

\section{Pohuda N.}

\section{TOURISM AS AN ECONOMIC DEVELOPMENT INDICATOR}

The article examines the modern indices of assessment of economic development of the country, the main purpose of which is to summarize the economic level of development of the country. In Ukraine, it is proposed to use the index of current economic capacity as an average measure of economic development. It is determined that most international indicators at the base of calculations include gross domestic product.

The dynamics of gross domestic product as a key indicator of the economy development is analyzed. It is noted that tourism has a significant impact on economies, if its share is 6-10\% of GDP. According to the research, this indicator in Ukraine is much lower than the desired level, and therefore the development of tourism is low.

The dynamics of income growth from the provision of tourist services has also been analyzed, which has led to the conclusion of a positive trend in tourism in recent years. 
Економічні науки: збірник наукових праџь Луцького національного технічного університету. - Серія "Регіональна економіка". - Випуск 16 (63). - Редкол.: відп. ред. д.е.н., професор Л.Л. Ковальська - Луцьк : ІВВ Луиького НТУ, 2019. - 173 с.

It is established that there is a close link between GDP and tourism development. This is explained by a number of factors, such as the increase in the number of tourist entities (including both individuals and individuals), which in turn influences GDP development. Also, as the number of services provided increases, the number of staff and budget allocations is correspondingly increasing. Secondly, the increase in the number of sales permits is a mediating factor for improving the economic situation in the country and, consequently, the growth of household income.

Key words: tourism, indicator, gross domestic product, development index.

\section{Погуда Н.В.}

\section{ТУРИЗМ КАК ИНДИКАТОР РАЗВИТИЯ ЭКОНОМИКИ}

В статье рассмотрены современные индексы оценки развития экономики страны. Проанализирована динамика валового внутреннего продукта и динамику роста доходов от предоставления туристических услуг. Установлено, что между показателем ВВП и развитием туризма существует тесная связь. Определена необходимость развития туризма как индикатора развития экономики.

Ключевые слова: туризм, индикатор, валовой внутренний продукт, индекс развития.

Постановка проблеми у загальному вигляді та їі зв'язок з важливими науковими і практичними завданнями. Інвестиційна привабливість кожної держави визначається рядом факторів, де одним із ключових індикаторів можна вважати i розвиток туризму. Адже інвестиції є стимулюючим фактором зростання економіки, збільшення виробництва та надання послуг, забезпечення значної кількості додаткових робочих місць, а отже, і росту валового внутрішнього продукту. Туризм $\epsilon$ найбільш динамічною сферою протягом останніх років та економічно вигідним напрямом ведення бізнесу. Тому можна говорити про існування зв'язку між рівнем розвитку туристичної сфери та розвитком національної економіки.

Аналіз досліджень, у яких започатковано вирішення проблеми. Розвиток туризму та його вплив на економіку держави розглядають багато науковців, найбільш значущий вплив у даній сфері мають праці таких вчених як Л. Дядечко [1], О. Любіцевої [2], М. Мальської [3], Т. Ткаченко [4]. Проблемам 
Економічні науки: збірник наукових праџь Луцького національного технічного університету. - Серія "Регіональна економіка". - Випуск 16 (63). - Редкол.: відп. ред. д.е.н., професор Л.Л. Ковальська - Луцьк : ІВВ Луиького НТУ, 2019. - 173 с.

визначення ключових індикаторів розвитку економіки присвячені дослідження Б. Данилишина, С. Герасименко, В. Головко [5]. Однак питанням взаємозв'язку та впливу туризму на економіку держави присвячено недостатньо уваги у наукових розробках.

Цілі статті. Метою статті $\epsilon$ аналіз динаміки розвитку туризму та дослідження впливу туризму на економіку держави.

$\begin{array}{ccccr}\text { Виклад основного } & \text { матеріалу } & \text { дослідження } & 3 \\ \text { обгрунтуванням отриманих } & \text { наукових } & \text { результатів. } & \text { У }\end{array}$ сучасних умовах про рівень розвитку економіки держави прийнято говорити більше за допомогою оцінки різних міжнародних показників, ніж за реальними економічними показниками такими як ВВП, ВНП, рівень зайнятості та безробіття, інфляція, експорт та імпорт. Зокрема, широко розповсюдження набувають у процесі оцінки такі міжнародні показники як індекс людського розвитку (який $є$ інтегральним показником рівня життя населення, освіти, ВВП на душу населення), індекс конкурентоспроможності країни (включає 12 показників), індекс економічної свободи (основу містять 10 показників). У той же час, національним індексом, що визначає рівень економічного розвитку держави $\epsilon$ індекс поточної економічної спроможності, який рекомендовано використовувати для оцінки соціально-економічного стану країни. Зазначені вище індекси є інтегральними показниками, що мають на меті оцінювати рівень розвитку економіки держави різносторонньо, враховуючи різні аспекти розвитку.

Попри існування широкого кола показників базовим для їх оцінки виступає показник ВВП, динаміку розвитку якого в Україні проілюстровано на рисунку 1.

Відповідно можемо зробити висновок, що показник ВВП має лінійну тенденцію до зростання та має позитивну динаміку.

Враховуючи світову практику, частка туризму у складі ВВП має становити 6-10\%, що свідчить про значний вплив даної сфери на економіку держави та його розвиток. У той же час, аналізуючи даний показник в Україні, його розмір коливається у межах 0,4-0,65\% [7]. Тобто рівень розвитку туризму $\epsilon$ 
Економічні науки: збірник наукових праџь Луцького національного технічного університету. - Серія "Регіональна економіка". - Випуск 16 (63). - Редкол.: відп. ред. д.е.н., професор Л.Л. Ковальська - Луцьк : ІВВ Луцького НТУ, 2019. -173 с.

незначним та має зростати, зокрема за рахунок удосконалення туристичної інфраструктури, законодавчого забезпечення та податкового стимулювання, зростання доходів населення тощо.

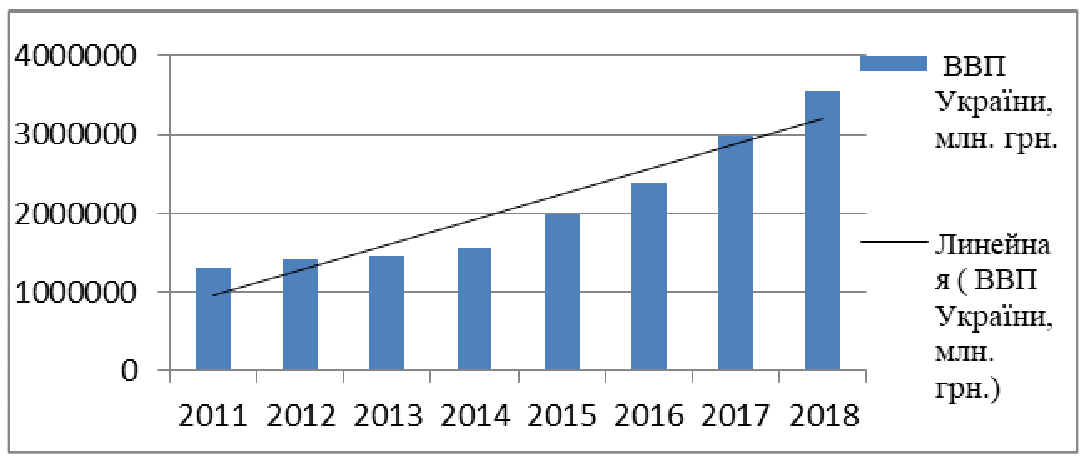

Рис.1. Динаміка валового внутрішнього продукту України протягом 2011-2018 pр. [побудовано автором на основі 6]

Стосовно тенденцій розвитку слід зауважити, що важливим показником розвитку туризму в країні $\epsilon$ дохід від надання туристичних послуг, динаміку якого можна прослідкувати за допомогою рисунку 2.

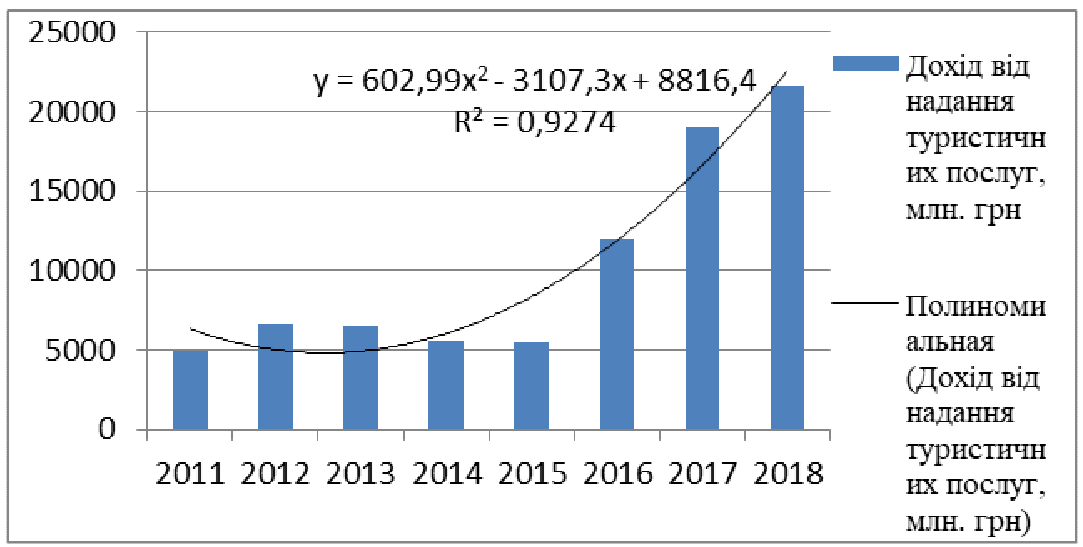

Рис. 2. Динаміка доходів від надання туристичних послуг в Україні, 2011-2018 рр. [побудовано автором на основі 6] 
Економічні науки: збірник наукових праџь Луцького національного технічного університету. - Серія "Регіональна економіка". - Випуск 16 (63). - Редкол.: відп. ред. д.е.н., професор Л.Л. Ковальська - Луцьк : ІВВ Луцького НТУ, 2019. - 173 с.

Так само позитивну динаміку протягом 2016-2018 років має i зростання доходу від надання туристичних послуг суб'єктами туристичної діяльності (юридичних та фізичних осіб). За допомогою поліноміальної функції встановлено, що достовірність використаних даних є високою і становить майже $93 \%$.

Отже, аналізуючи рис. 2, можна зробити висновок, що зростання даного показника обумовлено: по-перше, збільшенням кількості суб'єктів туристичної діяльності (у 2018 р. на $23 \%$ більше у порівнянні з 2017 р.), що у свою чергу, впливає на розвиток ВВП, оскільки зростає кількість наданих послуг, також спостерігається певне збільшення чисельності персоналу, відповідно і відрахувань до бюджету; по-друге, збільшенням кількості реалізованих путівок (понад $40 \%$ по відношенню до 2017 р.), що також пов'язано $з$ економічною ситуацією в країні, а отже, зростанням доходів населення.

Висновки. Розвиток туризму можна вважати індикатором і розвитку економіки, оскільки від ефективного функціонування даної сфери підприємницької діяльності суттєво залежить як розкриття i використання природного та антропогенного потенціалу туристичних територій, так і збільшення чисельності не лише туристів, але й реальних інвесторів. Туризм має вагомий вплив і на суміжні сфери, тим самим створюючи мультиплікативний ефект на економіку держави.

1. Дядечко Л.П. Економіка туристичного бізнесу / К.: Центр учбової літератури, 2007. 224 c.

2. Любіцева О.О. Ринок туристичних послуг (геопросторові аспекти) / К.: Альтерпрес, 2002. 436 с.

3. Мальська М.П., В.В. Худо, В.І. Цибух. Основи туристичного бізнесу: навчальний посібник / Київ: Центр навчальної літератури, 2004. 272 с.

4. Ткаченко Т.І. Сталий розвиток туризму: теорія, методологія, реалії бізнесу: монографія / Т.І. Ткаченко. К.: Київський національний торговельноекономічний університет, 2009. $463 \mathrm{c}$.

5. Герасименко С., В. Головко, І. Нікітіна.Система національних рахунків: навч. посіб. / Харків: ХНУ, 2005. 217с.

6. Офіційний сайт Державної служби статистики України [Електронний pecypc]. Режим доступу: http://www.ukrstat.gov.ua 
Економічні науки: збірник наукових праць Луиького національного технічного університету. - Серія "Регіональна економіка". - Випуск 16 (63). - Редкол.: відп. ред. д.е.н., професор Л.Л. Ковальська - Луцьк : ІВВ Луиького НТУ, 2019. - 173 с.

7. Погуда Н., О. Розметова Сучасний стан туристичного ринку України: оцінка та перспективи розвитку / // Ефективна економіка. [Електронний pecypc]. Режим доступу: http://www.economy.nayka.com.ua/?op=1\&z=6608 